in host requirements and capable of germinating, and completing its life-cycle, with the production of viable seeds, in the absence of a host.

Host plants (Trifolium repens) parasitized by individuals of Odontites verna were grown in pot culture. Individual leaves of the host were exposed to ${ }^{14} \mathrm{CO}_{2}$, in the light, for $24 \mathrm{~h}$. The pairs of plants were then freeze-dried, mounted and exposed to X-ray plates. Fig. 1 shows one of the resulting autoradiographs demonstrating the presence, in the hemiparasite, of carbon-containing compounds from the host plant. Similar ${ }^{14} \mathrm{C}$ transfer to the parasite has been observed from gramineous hosts. No transfer occurred when parasite and host were growing together but without haustorial union.

The demonstration that both Odontites and Striga receive assimilates from a host plant may indicate that this is a general characteristic of the Rhinanthoideae.

One of us (R. N. G.) thanks the Agricultural Research Council for the award of a scholarship.

R. N. GOVIER J. L. HARPER

Department of Agricultural Botany,

University College of North Wales, Bangor.

${ }^{1}$ Koch, L., Jahrb. f. wiss. Bot., 20, 33 (1889).

2 Ewart, A. J., J. Linn. Soc. Bot., 31, 364 (1895).

Kostytschew, S., Beihefte z. Bot. Centrlblatt., 40, 351 (1923).

- Heinricher, E., Ber d. deutsch. Bot. Ges., 42, 243 (1924).

- Bonnier, G., Bull. de la Soc. de Biol., 651 (1889); C.R. Soc. Biol., 113, $1074(1891) ;$ Bull. scient. du Nord de la France et de la Belgique, 25, 77 (1893).

'Rogers, W. E., and Nelson, R. R., Phytopathology, 52, 1064 (1962).

\section{Long-distance Migration of Atlantic Salmon}

Is recent years a number of authors have reported the recapture in the Greenland area of salmon originally tagged as either smolts or spent fish in British, Canadian and Swedish waters ${ }^{1}$. During the month of October 1964 four salmon originally tagged in rivers in the west of Ireland in County Mayo as clean or spent fish have been reported as having been recaptured off the west coast of Greenland. The details are given in Table 1.

\begin{tabular}{|c|c|c|c|}
\hline Date & $\begin{array}{l}\text { Release data } \\
\text { Place }\end{array}$ & $\begin{array}{c}\text { Tab } \\
\text { Date }\end{array}$ & $\begin{array}{c}\text { Recapture data } \\
\text { Place }\end{array}$ \\
\hline $5 / 9 / 63$ & Carrowmore Lake & $6 / 10 / 64$ & Near Julianehaab $\left(60^{\circ} 40^{\prime} \mathrm{N}, 46^{\circ} 15^{\prime}\right.$ \\
\hline $12 / 9 / 63$ & Carrowmore Lake & $21 / 10 / 64$ & Near Suppertoppen $\left(65^{\circ} 25^{\prime} \mathrm{N}, 53^{\circ}\right.$ \\
\hline $\begin{array}{l}25 / 3 / 64 \\
25 / 4 / 64\end{array}$ & $\begin{array}{l}\text { Burrishoole River } \\
\text { Burrishoole River }\end{array}$ & $\begin{array}{l}18 / 10 / 64 \\
17 / 10 / 64\end{array}$ & $\begin{array}{l}\text { Off Kangamiut }\left(65^{\circ} 49^{\prime} \mathrm{N}, 53^{\circ} 19^{\prime} \mathrm{W}\right) \\
\text { Off Kangamiut }\left(65^{\circ} 49^{\prime} \mathrm{N}, 53^{\circ} 19^{\prime} \mathrm{W}\right)\end{array}$ \\
\hline
\end{tabular}

The first two fish were tagged by an official of the Fisheries Division of the Department of Lands, Dublin, and the second by officials of the Salmon Research Trust of Ireland, Inc., sponsored by Arthur Guinness, Son and Co., Ltd., and the Minister for Lands for Ireland. Arthur E. J. Went

Fisheries Division, Department of Lands, Dublin.

Salmon Research Trust of Ireland, Inc.,

David J. Piggins

Furnace, Newport, Co. Mayo.

'Allan, I. R. H., and Bulleid, M. J., Nature, 200, 89 (1963).

\section{MICROBIOLOGY}

\section{Effect of $\mathrm{pH}$ and Temperature on Structural Integrity of an L Form of Streptococcus pyogenes}

$L$ FoRMs obtained from group $A$ Streptococci are osmotically fragile. Suspensions of the $L$ form, which lacks the rigid bacterial cell wall, in osmotically unprotective environments results in structural disintegration and loss of viability ${ }^{1}$. A paucity prevails in the literature, however, concerning the effect of temperature and $p H$ on the integrity of the $L$ form in its protective growth medium. This communication deals with a comparison of the effect of such alterations of the growth environment on the structural stability of a group $A$ - $\beta$-haemolytic Streptococcus and a derived stable $L$ form obtained from it with the aid of penicillin.

The Streptococcus and $L$ form are the same as those used earlier ${ }^{2}$. The medium for each of these organisms was described $^{\mathbf{3}}$. Sterilization of all media by either heat or filtration afforded identical results. For these investigations, $50 \mathrm{ml}$. of media in $125 \mathrm{ml}$. Erlenmeyer flasks equipped with side-arm tubes were inoculated with 0.5 and $1.0 \mathrm{ml}$. of overnight cultures of the coccus and $L$ form, respectively. All incubations $\left( \pm 0.25^{\circ} \mathrm{C}\right)$ were performed in a thermostatically controlled water bath. Each organism was grown at $37^{\circ} \mathrm{C}$ until an optical density of between $0 \cdot 250-0 \cdot 300$ (approximately mid-logarithmic growth) was attained before adjusting cultures to the experimental $p H$ with small volumes of either concentrated sodium hydroxide or hydrochloric acid. Cultures were transferred to water baths adjusted to the desired temperature and lysis followed spectrophotometrically; growth and lysis being determined at frequent intervals with a Coleman model 14 spectrophotometer at $650 \mathrm{~m} \mu$. The temperatures and $p \mathrm{H}$ 's examined are indicated in one of the figures. Un-inoculated media served as blanks for growth; $p \mathrm{H}$-adjusted aliquots of the supernate of collected cultures served as blanks for the lysis investigation. Each value is an average of two determinations. Only logarithmic coccal and $L$ form cultures, the growth rates of which (doublings/h) at $37 \mathrm{C}$ were close to $1 \cdot 1$ and 0.7 respectively, were used. The rate of $L$-form lysis is expressed as the negative slope of a culture that had undergone at least 50 per cent lysis within $50 \mathrm{~min}$.

Fig. 1 illustrates a typical example of the effect of an increase in $p H$ on the structure of logarithmically growing coccal cells before and after cell wall removal (that is, stable $L$ form). Fig. 2 summarizes the results of temperature and $p \mathrm{H}$ alterations of the growth medium on structural stability. As is apparent, $L$ form structural disintegration was most pronounced at $48^{\circ} \mathrm{C}$, with maximum destruction of cell structure occurring in combination with a $p \mathrm{H}$ of 9 (Fig. 2). The decrease in turbidity was correlated with $L$ form structural disintegration by dark phase-

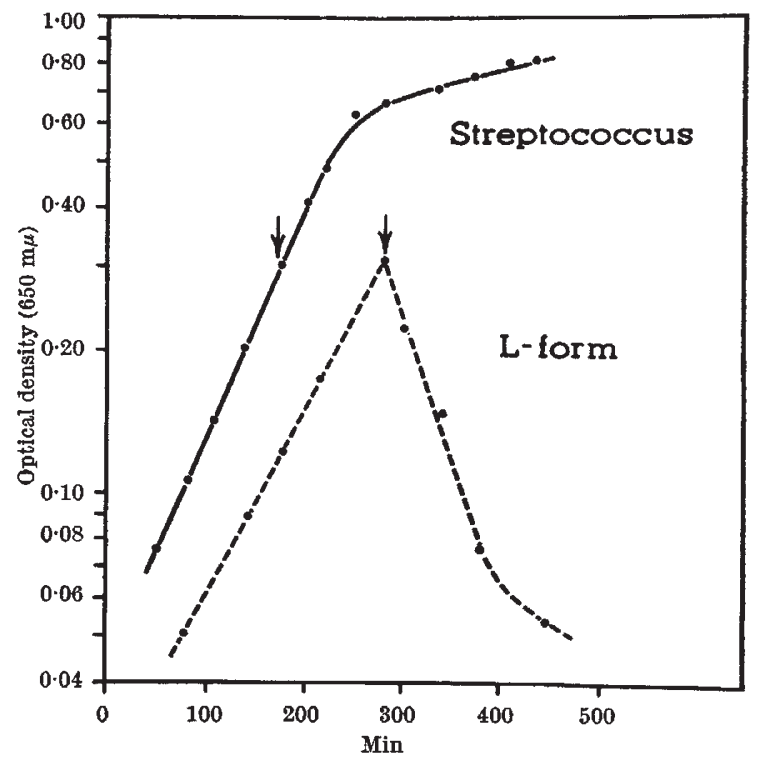

Fig. 1. Effect of $p H$ increase on structural stablity of the coccus and derived $L$ form. Arrows indicate time each culture was adjusted to $p$ H 9 and reincubated at the growth temperature $\left(34^{\circ} \mathrm{C}\right)$. Growth and lysis
rates determined from the stralght line portion of curves after $p \mathbf{H}$ and temperature changes 